\title{
WADAH AKTIVITAS MASYARAKAT DI TANAH SEREAL
}

\author{
Chantika Mayadewi ${ }^{11}$, Dewi Ratnaningrum ${ }^{2)}$ \\ 1)Program Studi S1 Arsitektur, Fakultas Teknik, Universitas Tarumanagara, chantikamayadewii@gmail.com \\ 2)Program Studi S1 Arsitektur, Fakultas Teknik, Universitas Tarumanagara, dewitrionotasman@gmail.com
}

Masuk: 09-01-2020, revisi: 28-01-2020, diterima untuk diterbitkan: 09-05-2020 (doi: 10.24912/stupa.v2i1.6758)

\begin{abstract}
Abstrak
Sebagai makhluk sosial, manusia tentunya membutuhkan interaksi sosial dengan sesamanya, namun seringkali tidak memiliki wadah yang layak untuk mendukung terjadinya interaksi tersebut. Terutama di permukiman padat penduduk dengan keterbatasan lahan terbuka seperti di Kelurahan Tanah Sereal, Kecamatan Tambora, Jakarta Barat, di mana masyarakat menjadikan jalan dan gang-gang sempit sebagai tempat untuk melakukan berbagai aktivitas. Di sisi lain, zaman modern dengan teknologi yang semakin berkembang membuat masyarakat menjadi semakin inklusif dan individual, sehingga diperlukan fasilitas di mana warga dapat melaksanakan kegiatan bersama sebagai kegiatan di luar tempat tinggal (first place) dan tempat kerja (second place) disebut sebagai tempat ketiga atau third place yang dapat menjawab berbagai kebutuhan sosial dan ruang hijau kota di kawasan padat penduduk. Pada penelitian ini metode yang digunakan adalah metode konvensional yaitu analisis-sintesis yang meliputi pengumpulan data (input), analisis (proses), dan sintesis (output). Data didapat dari pengamatan grounded ke lapangan, wawancara dengan warga sekitar, kajian literatur, serta mapping kawasan. Proyek third place yang ada di Tanah Sereal ini berjudul Wadah Aktivitas Masyarakat di Tanah Sereal, bertujuan untuk menyediakan sebuah wadah aktivitas bagi warga permukiman padat dalam memiliki ruang aktivitas bersama atau third place yang terintegrasi dengan gang hijau untuk mengatasi permasalahan sosial dan lingkungan di kawasan padat penduduk. Proyek ini memiliki program utama yaitu area tanam hidroponik (urban farming), dilengkapi dengan foodcourt, area bermain, area diskusi remaja, area komunal, ruang seminar, balai serbaguna, serta program pengembangan masyarakat seperti workshop hidroponik dan workshop garmen untuk meningkatkan skill, produktivitas, dan taraf hidup masyarakat sekitar.
\end{abstract}

Kata kunci: hidroponik; komunitas; tanah sereal; tempat ketiga

\begin{abstract}
As social beings, humans naturally need social interaction with others, but often do not have a proper place to support the interaction. Especially in densely populated settlements with limited open space such as in Tanah Sereal, Tambora District, West Jakarta, where community makes the streets and narrow alleys as a place to do various activities. On the other hand, modern times with increasingly evolving technology make society more inclusive and individual, so a facility is needed where residents can carry out joint activities outside the place of residence (first place) and work place (second place) reffered to as the third place that can answer various social needs and urban green spaces in densely populated areas. The method that is used in this study is the conventional method of analysis-synthesis which includes data collection (input), analysis (process), and synthesis (output). Data is obtained from grounded observations, interviews with local residents, literature studies, as well as regional mappings. The third place project in Tanah Sereal is titled Tanah Sereal Commuity Activity Space, which is intended to provide a place of activities for residents of dense settlements in having a shared activity space or a third place that is intergrated with green alley to address social and environmental problems in densely populated areas. The main program of the building is hydroponic planting areas (urban farming), equipped with foodcourt, play areas, teenage discussion areas, communal areas, seminar room, temporary event room, as well as community development program such as hydroponic workshop and garment workshop aimed at improving the skills, productivity, and standard of living of surrounding communities.
\end{abstract}

Keywords: community; hydroponic; tanah sereal; third place 


\section{PENDAHULUAN}

Kota merupakan pusat beragam aktivitas yang dilengkapi dengan sarana dan prasarana yang dapat menunjang kualitas hidup yang lebih baik. Keberadaan fasilitas yang ada di kota pun menjadi sebuah daya tarik tersendiri bagi masyarakat daerah untuk datang dan menetap di perkotaan, mulai dari fasilitas pendidikan, kesehatan, perekonomian, industri, transportasi, dan sebagainya. Besarnya laju urbanisasi dan pertumbuhan yang ada di dalam kota tersebut menimbulkan berbagai masalah perkotaan, salah satunya adalah masalah kepadatan penduduk.

UN Habitat (2018) menyatakan bahwa dua per tiga dari populasi dunia akan tinggal di perkotaan dan ibu kota pada tahun 2050. Fenomena ini dapat terjadi di Jakarta sebagai ibukota Indonesia, Negara dengan populasi penduduk terbanyak keempat di dunia (CIA, 2018). Meningkatnya pertumbuhan penduduk dan urbanisasi di Jakarta juga diiringi oleh tuntutan pembangunan ruang kota, sehingga terjadi pengalihan dan penyalahgunaan fungsi lahan dari ruang terbuka hijau menjadi daerah permukiman maupun komersial untuk memenuhi kebutuhan masyarakat yang semakin meningkat. Akibatnya, penghijauan minimal $30 \%$ luas wiilayah kota yang ditetapkan oleh pemerintah dalam Undang-Undang No. 26 Tahun 2007 belum juga memadai.

Menurut Badan Pusat Statistik (2018), Jakarta Barat merupakan wilayah kota administrasi terpadat di DKI Jakarta. Salah satu kawasan yang mendorong fenomena ini adalah Kelurahan Tanah Sereal, Kecamatan Tambora. Kecamatan Tambora sendiri terkenal sebagai kecamatan terpadat di Jakarta Barat dan Asia Tenggara (Djaharuddin, 2018).

Kepadatan di Tanah Sereal umumnya didominasi oleh penyebaran permukiman secara horizontal. Seiring dengan waktu, timbul ketidakseimbangan antara kebutuhan yang terus meningkat dan ketersediaan lahan yang semakin terbatas. Proporsi lahan yang tertutup perkerasan semakin besar dan mengakibatkan berbagai masalah lingkungan seperti masalah sanitasi dan kebakaran. Selain aspek ekologis, terdapat gangguan dari aspek sosial di mana warga semakin kekurangan ruang-ruang terbuka sebagai tempat untuk beraktivitas dan berinteraksi dengan sesamanya.

Sebagai makhluk sosial, manusia tentunya membutuhkan interaksi sosial dengan sesamanya, namun seringkali tidak memiliki wadah yang layak untuk mendukung terjadinya interaksi tersebut. Terutama di permukiman padat penduduk dengan keterbatasan lahan terbuka hijau yang ada, menjadikan jalan dan gang-gang sempit sebagai tempat untuk melakukan berbagai aktivitas. Di sisi lain, zaman modern dengan teknologi yang semakin berkembang membuat masyarakat menjadi semakin inklusif dan individual. Oleh karena itu, diperlukan sebuah wadah yang dapat menaungi kegiatan-kegiatan sosial masyarakat yang terlepas dari tempat tinggal (first place) dan tempat kerja (second place) disebut sebagai tempat ketiga atau third place yang dapat menjawab berbagai kebutuhan sosial dan ruang hijau kota di kawasan padat penduduk. Wadah Aktivitas Masyarakat di Tanah Sereal ini hadir untuk menjawab isu tersebut.

\section{KAJIAN LITERATUR}

\section{Third Place}

Oldenburg (1999) menyatakan bahwa third place adalah ruang antara di mana manusia menghabiskan waktunya selain di rumah (first place) dan tempat kerja atau sekolah (second place). Third place adalah sebuah program yang akan membantu masyarakat kota agar bersifat humanis, terbuka, dinamis, dan produktif.

Third place memiliki peran yang besar dalam kehidupan bermasyarakat dan selanjutnya dalam mendefinisikan image sebuah kota. Seperti café pinggir jalan identik dengan kota Paris dan forum identik dengan Roma Klasik, third place adalah tempat berkumpul publik informal yang memiliki perbedaan khasnya tersendiri di setiap kota. 
Terdapat 8 karakteristik third place yaitu netral, level, aktivitas utama adalah perbincangan, memiliki jam buka yang panjang dan mudah diakses, mempunyai regular, berpenampilan yang polos dan sederhana, memiliki suasana yang playful, dan adalah rumah yang jauh dari rumah.

\section{Kepadatan Penduduk}

Kepadatan penduduk adalah perbandingan antara jumlah penduduk dengan luas wilayah yang dihuni (Mantra, 2007). Beberapa faktor yang mempengaruhi kepadatan penduduk adalah natalitas (kelahiran), mortalitas (kematian), dan migrasi (perpindahan).

Kepadatan penduduk dapat mempengaruhi kualitas hidup penduduknya. Beberapa dampak yang disebabkan oleh kepadatan penduduk adalah munculnya kawasan-kawasan kumuh kota dengan rumah-rumah yang tidak layak huni, tingginya kompetisi di dunia kerja, terganggunya stabilitas keamanan, dan berkurangnya ruang terbuka sebagai tempat untuk bersosialisasi dan ruang terbuka hijau sebagai tempat resapan air kota.

\section{Ruang Terbuka Hijau}

Ruang terbuka tidak dapat dipisahkan dari manusia baik secara psikologis, emosional, ataupun dimensional. Manusia berada di dalam ruang, bergerak, menghayati, dan berpikir, juga membuat ruang untuk menciptakan dunianya. (Budiharjo dan Sujarto, 1999).

Undang-undang No. 26 Tahun 2007 tentang Penataan Ruang menyatakan bahwa Ruang Terbuka Hijau (RTH) adalah area memanjang/jalur dan/atau mengelompok, yang penggunaannya lebih bersifat terbuka, tempat tumbuh tanaman, baik yang tumbuh secara alamiah maupun yang sengaja ditanam. Ruang Terbuka Hijau memiliki beberapa fungsi, yaitu fungsi ekologis, sosial dan budaya, ekonomi, dan arsitektural atau estetika.

Penyediaan RTH berdasarkan luas wilayah di perkotaan terbagi menjadi dua, yaitu RTH publik dan RTH privat. Proporsi RTH pada wilayah perkotaan adalah minimal $30 \%$ luas wilayah kota dengan $20 \%$ RTH publik dan $10 \%$ RTH privat. Apabila luas RTH di kota yang bersangkutan telah mencapai total luas lebih besar dari peraturan, maka proporsi tersebut harus tetap dipertahankan keadaannya.

\section{Urban Farming}

Urban farming berasal dari bahasa Inggris yaitu "urban" yang artinya perkotaan dan "farming" yang artinya pertanian. Definisi pertanian perkotaan adalah kegiatan pertanian kota yang dilakukan di lingkungan kota sebagai salah satu bentuk ruang terbuka hijau (RTH) produktif yang bernilai ekonomi dan ekologi (Widyawati, 2013). Menurut Indonesia Berkebun (2015), urban farming memiliki konsep 3E yaitu Ekologi (mengembalikan kesuburan tanah), Ekonomi (menciptakan ketahanan pangan), dan Edukasi (memberikan pendidikan ke publik untuk cinta lingkungan). Beberapa cara bercocok tanam yang cocok di perkotaan yang kekurangan lahan tidur adalah dengan sistem hidroponik dan metode tabulampot atau tanaman buah dalam pot.

\section{Sistem Hidroponik}

Hidroponik adalah istilah yang digunakan untuk menjelaskan beberapa cara bercocok tanam tanpa menggunakan tanah sebagai media tanam. Hidroponik berasal dari bahasa Yunani yang terdiri dari kata hydro yang berarti air dan ponos yang berarti kerja. Jadi hidroponik dapat diartikan sebagai pengerjaan atau pengelolaan air yang digunakan sebagai media tumbuh tanaman dan tempat akar tanaman mengambil unsur hara yang diperlukan. Umumnya media tanam yang digunakan bersifat poros seperti pasir, arang sekam, batu apung, kerikil, dan rockwool (Lingga, 1999).

Prinsip dasar budidaya tanaman hidroponik adalah merekayasa alam dengan menciptakan dan mengatur kondisi lingkungan yang ideal bagi perkembangan dan pertumbuhan tanaman sehingga ketergantungan tanaman terhadap alam dapat dikendalikan. Rekayasa fakor lingkungan yang paling menonjol pada sistem ini adalah dalam hal penyediaan nutrisi. Di mana 
nutrisi disediakan untuk tanaman dalam jumlah yang tepat dan mudah diserap oleh tanaman untuk mengoptimalkan pertumbuhan (Lingga, 1986).

Kristi (2018) menyatakan terdapat beberapa sistem instalasi hidroponik yang mudah untuk diterapkan yaitu sistem NFT (Nutrient Film Technique), drip system (sistem tetes), ebb\&flow system (sistem pasang surut), water culture system (sistem rakit apung), aeroponic system (aeroponik), dan wick system (sistem sumbu). Sistem-sistem ini memerlukan pasokan air dan listrik yang cukup banyak, karena beberapa sistem menggunakan timer untuk mengalirkan air nutrisi ke akar tanaman. Terdapat beberapa tanaman yang mudah dibudidayakan dengan sistem hidroponik, yaitu kangkung, bayam, sawi, brokoli, selada hijau, cabai, seledri, melon, semangka, tomat, sage, oregano, bangun-bangun, dan thyme.

\section{METODE}

Pada penelitian ini metode yang dipakai adalah metode konvensional yaitu analisis-sintesis yang meliputi pengumpulan data (input), analisis (proses), dan sintesis (output). Proyek adalah third place untuk masyarakat, sehingga diperlukan pengamatan grounded secara langsung (survei lapangan) untuk melihat kebutuhan penduduk. Mapping kawasan seperti mapping solid-void, penghijauan, intensitas kebakaran, letak pemadam kebakaran, land use existing, kriminalitas, kegiatan sosial, dan kegiatan ekonomi dan tenaga kerja masyarakat juga dibutuhkan untuk analisis desain dan program kedepannya.

Program ruang didapat dari analisis perilaku, aktivitas, dan kebutuhan penduduk melalui pengamatan dan wawancara langsung dengan warga sekitar. Setelah itu dilakukan analisis mikro secara tapak untuk menemukan fungsi, bentuk dan tampilan, serta struktur dan utilitas yang sesuai sehingga menghasilkan sintesis atau output berupa desain bangunan.

\section{DISKUSI DAN HASIL}

Proyek ini dinamakan sebagai Wadah Aktivitas Masyarakat di Tanah Sereal (Tanah Sereal Community Activity Space). Sesuai namanya, wadah aktivitas ini berfungsi untuk menampung berbagai jenis aktivitas masyarakat heterogen yang ada di Tanah Sereal terlepas dari tempat kerja dan tempat tinggal.

Proyek berada di Jl. Pekapuran II, Kelurahan Tanah Sereal, Kecamatan Tambora, Jakarta Barat. Lokasi proyek dikelilingi oleh permukiman padat penduduk setinggi 1-2 lantai dan ruko atau kantor lama setinggi 4 lantai. Tapak existing adalah permukiman padat penduduk yang tidak sesuai dengan rencana tata ruang. Terdapat pelebaran jalan di depan tapak yang akan membuat tapak lebih mudah di akses oleh publik.

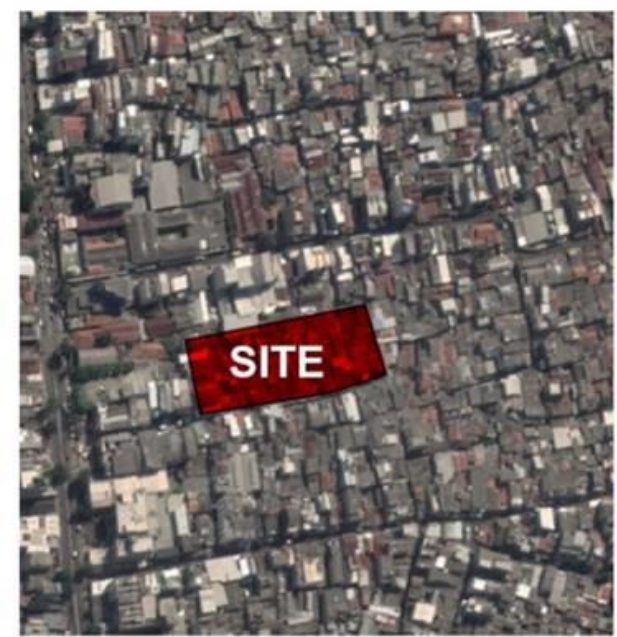

Kondisi existing

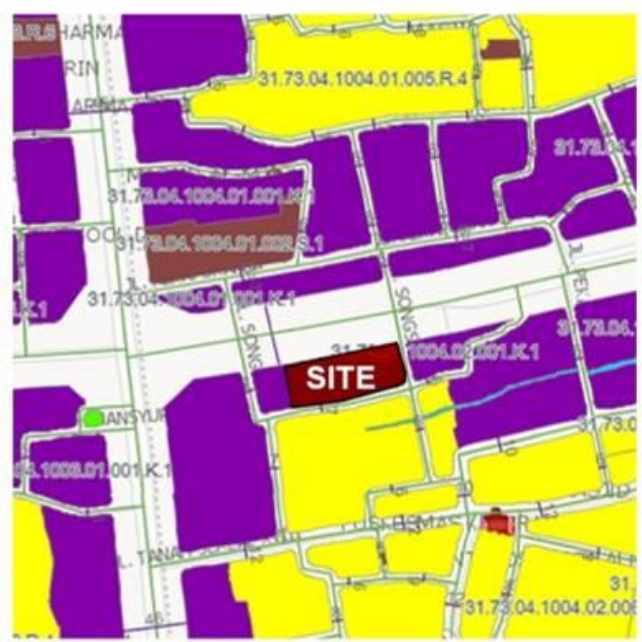

RDTR

Gambar 1. Lokasi Tapak dan rencana RDTR

Sumber: Google earth 2019 dan jakartasatu.com 


\section{Data Tapak}

Luas lahan: $2.740 \mathrm{~m} 2$

Zonasi: K1 (Perkantoran, Perdagangan, dan Jasa)

\section{Sub Zona: 001.K.1}
KDB: $75 \%$ (maksimal 2.055m2)
$\mathrm{KDH}: 30 \%$ (minimal $822 \mathrm{~m} 2$ )
KLB: 3 (maksimal $8.220 \mathrm{~m} 2$ )
KB: 4

Konsep desain dari Wadah Aktivitas Masyarakat di Tanah Sereal difokuskan pada interaksi antar manusia dan manusia dengan alam, diterjemahkan dalam arsitektur mulai dari pembentukan massa bangunan yang memiliki solid-void untuk membuka peluang adanya interaksi manusia secara visual dan penambahan unsur alam dalam bangunan seperti dengan adanya inner courtyard.
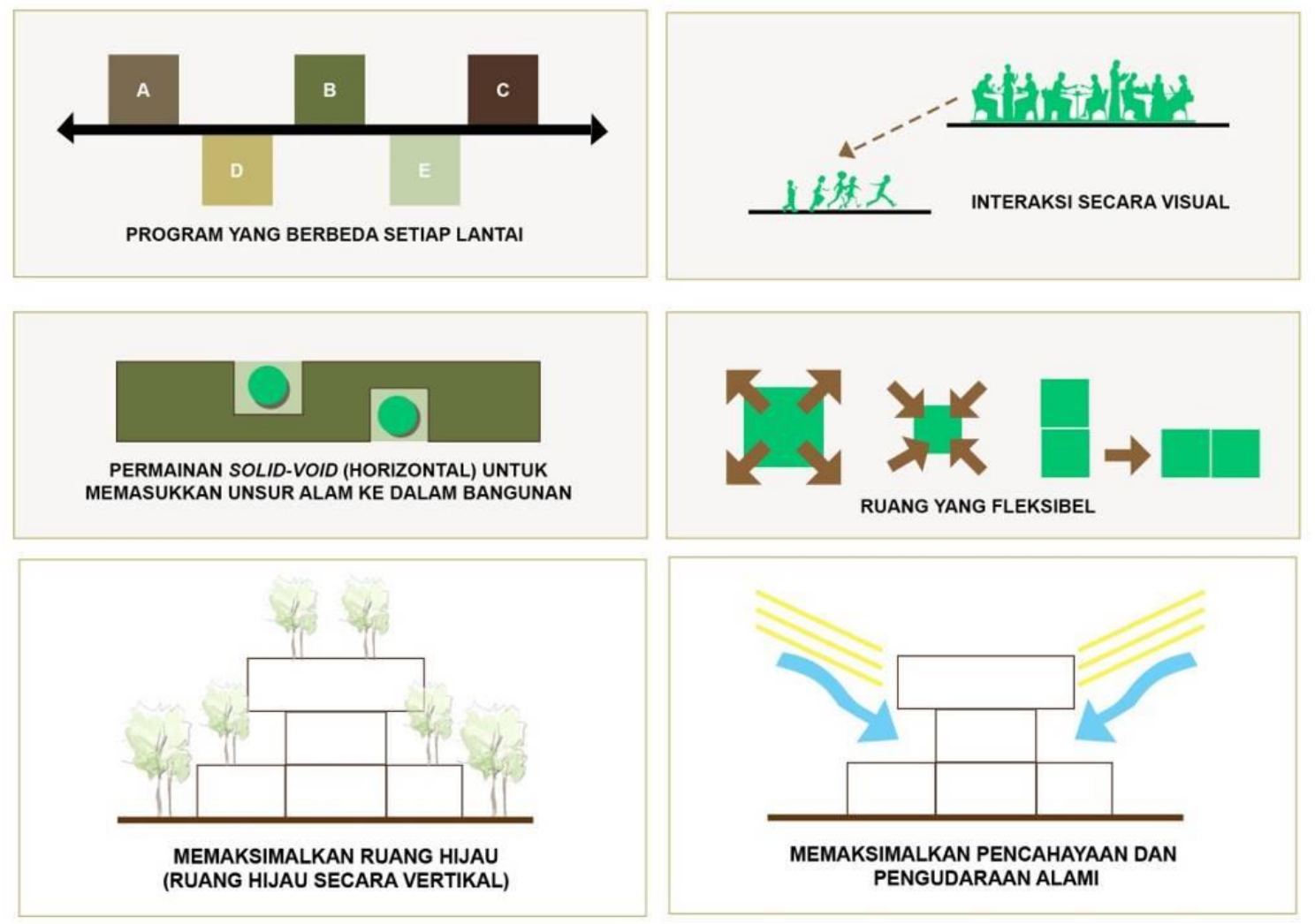

Gambar 2. Konsep Bangunan

Sumber: Penulis, 2019

Massa bangunan dibuat sederhana dengan unsur bentuk dasar kotak yang dibuat maju mundur. Terdapat banyak bukaan pada bangunan untuk memaksimalkan pencahayaan dan pengudaraan alami. Proyek juga memaksimalkan ruang hijau sebagai sumbangan untuk kota dengan cara mematuhi peraturan pemerintah dalam pembangunan dan membangun ruang hijau secara vertikal untuk mendorong masyarakat agar lebih peduli dengan lingkungan selain sebagai tempat untuk relaksasi.

Sesuai dengan judul proyek, wadah aktivitas masyarakat ini menampung berbagai jenis aktivitas masyarakat yang ada di Tanah Sereal dan diwujudkan dalam bentuk program yang berbeda di setiap sudut bangunan. Meskipun memiliki program yang banyak, ukuran tapak tergolong cukup kecil sehingga strategi desainnya adalah dengan menyediakan ruang yang fleksibel, salah satunya adalah dengan menggunakan rotating door untuk memberikan kesan ruang yang lebih luas dan terbuka. Proses desain didapat dari analisis tapak sebagai berikut: 


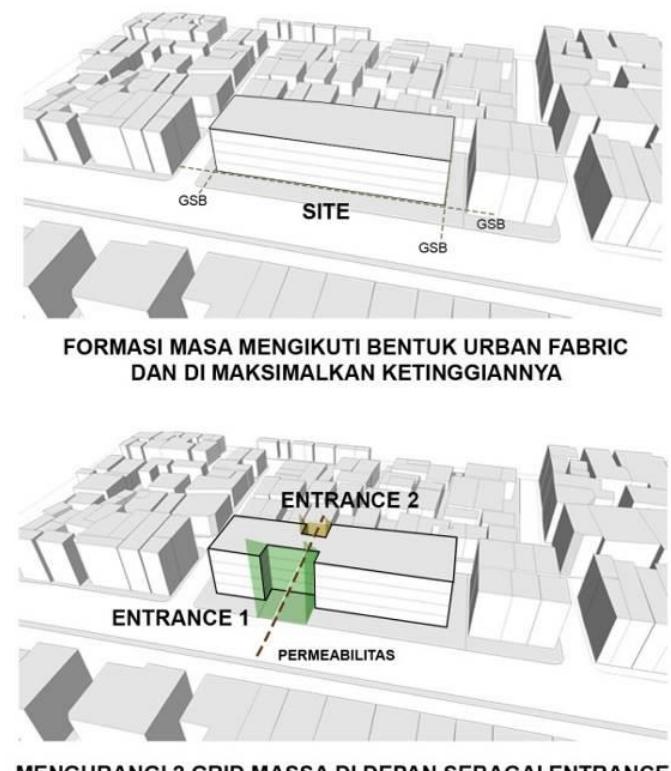

MENGURANGI 2 GRID MASSA DI DEPAN SEBAGAI ENTRANCE UNTUK KOTA DAN 1 GRID DI BELAKANG UNTUK MASYARAKAT

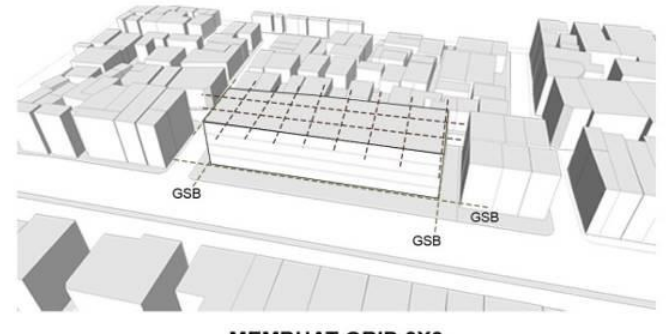

MEMBUAT GRID 8X8

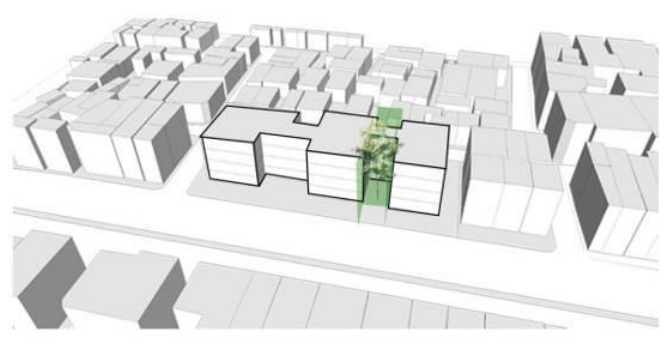

MASA DIBUAT MAJU MUNDUR UNTUK MEMASUKKAN UNSUR ALAM KE DALAM BANGUNAN

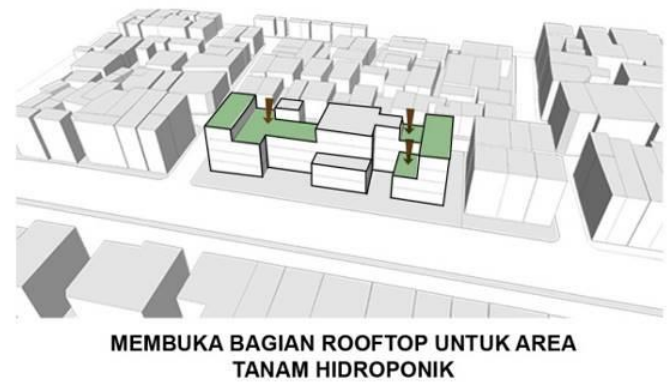

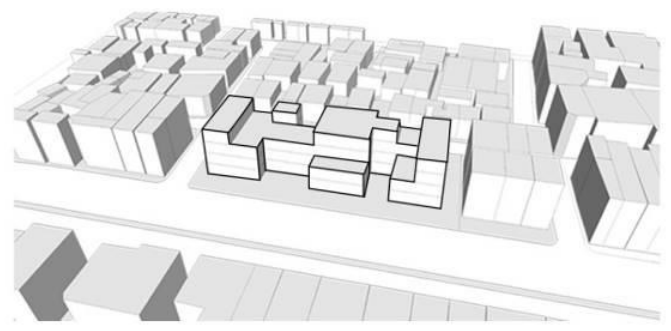

BENTUK MASSA FINAL

Gambar 3. Skematik Desain

Sumber: Penulis, 2019

Pembentukkan gubahan dimulai dari memaksimalkan massa bangunan yang diperbolehkan sesuai dengan peraturan di mana formasi massa mengikuti bentuk urban fabric yang ada untuk menyelaraskan bangunan dengan lingkungan sekitarnya. Massa kemudian dibagi dalam bentuk grid dasar bentuk kotak ukuran 8x8m dan dikurangi beberapa gridnya sebagai pintu masuk untuk kota dan masyarakat lokal. Entrance untuk kota (Jl. Pekapuran II) dibuat lebih besar untuk memberikan kesan mengudang, sedangkan entrance untuk masyarakat (JI. Tanah Sereal XIV) dibuat lebih kecil supaya memberi kesan ramah dan humanis.

Setelah itu, massa dibuat maju mundur sesuai dengan gridnya untuk memasukkan unsur alam ke dalam bangunan. Beberapa grid massa juga diturunkan untuk membuat permainan bentuk dan memaksimalkan cahaya matahari ke dalam bangunan. Terakhir adalah membuka area atap untuk area tanam hidroponik sehingga membentuk gubahan massa akhir. 


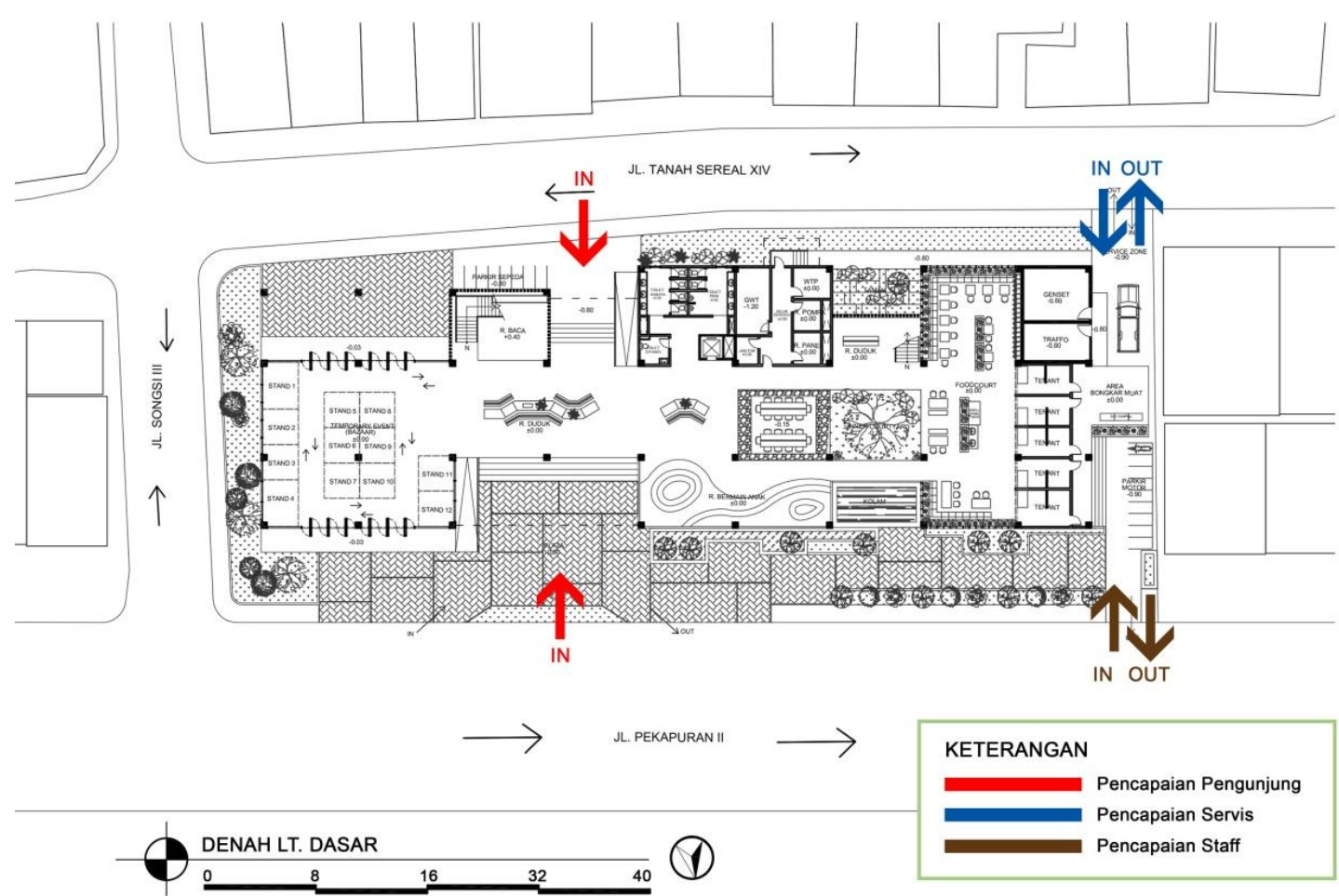

Gambar 4. Denah Lt. Dasar Sumber: Penulis, 2019

Penyusunan program pada perancangan beriorientasi pada bagian tengah yaitu ruang komunal dan ruang servis untuk memaksimalkan efisiensi utilitas bangunan. Sirkulasi utama bangunan adalah lift di bagian tengah dan dua buah tangga di sisi kiri dan kanan bangunan. Lift juga berfungsi untuk servis bangunan mengingat bangunan adalah bangunan masyarakat yang sederhana. Selain untuk sirkulasi, tangga juga berfungsi sebagai jalur evakuasi. Tangga didesain lebih terbuka untuk mengeluarkan asap ketika kebakaran terjadi. Pengunjung diberi kebebasan untuk mengeksplor bangunan dengan program-program yang berbeda di setiap sudut bangunan.

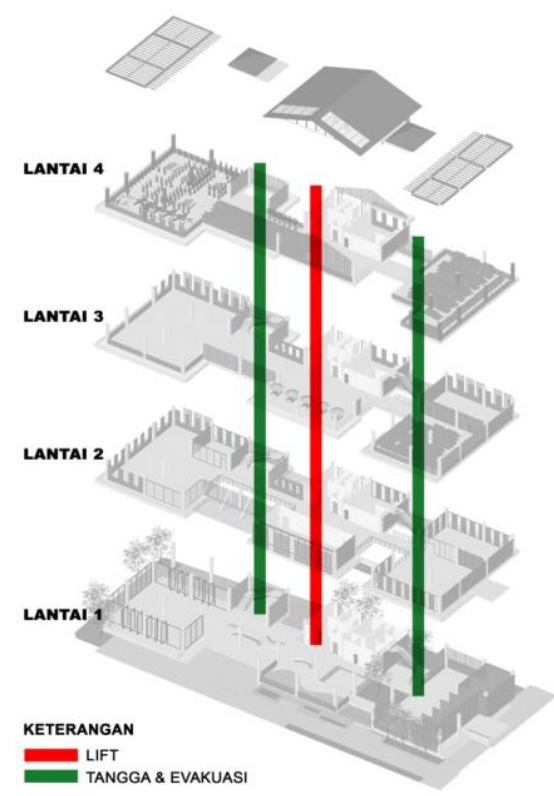

Gambar 5. Sirkulasi Bangunan Sumber: Penulis, 2019 


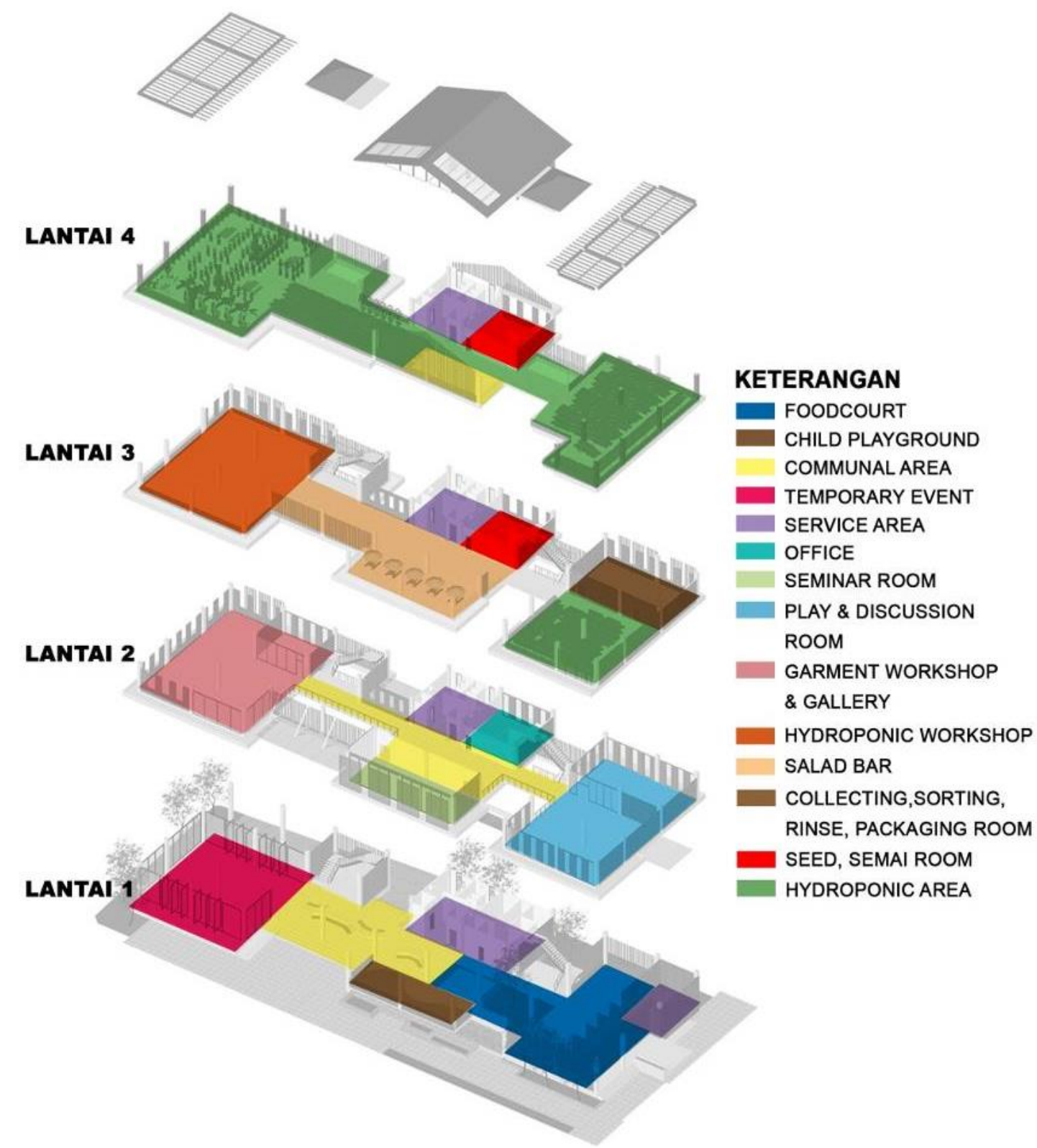

Gambar 6. Zoning Bangunan

Sumber: Penulis, 2019

Lantai 1 adalah zona publik yang bisa diakses oleh semua orang, menerapkan konsep permeabilitas yang menghubungkan jalan besar dan jalan lokal warga. Terdapat temporary event atau balai serbaguna yang flexible digunakan untuk acara-acara komunitas yang besar seperti bazaar hari raya, donor darah, dan sebagainya. Sewaktu-waktu ruang ini juga dapat menjadi pameran karya workshop garmen yang ada di lantai 2, juga menjadi pasar kecil-kecilan ketika ada panen besar dari area tanam urban farming di lantai rooftop. Ruang ini memiliki rotating door yang dapat membuat kesan ruangan lebih luas. Raised floor yang ada pada keseluruhan bangunan setingi $80 \mathrm{~cm}$ juga dapat membuat balai ini sewaktu-waktu dapat menjadi panggung pertunjukan skala kecil.

Foodcourt dan area anak-anak dibuat berdekatan dengan inner courtyard untuk memberikan kesan blur pada ruang dalam dan ruang luar, sehingga memungkinkan untuk memasukkan penghijauan pada bangunan. Design foodcourt menggunakan kursi-kursi yang saling berdempetan untuk membuka peluang sesama masyarakat saling berinteraksi dan berbagi. 


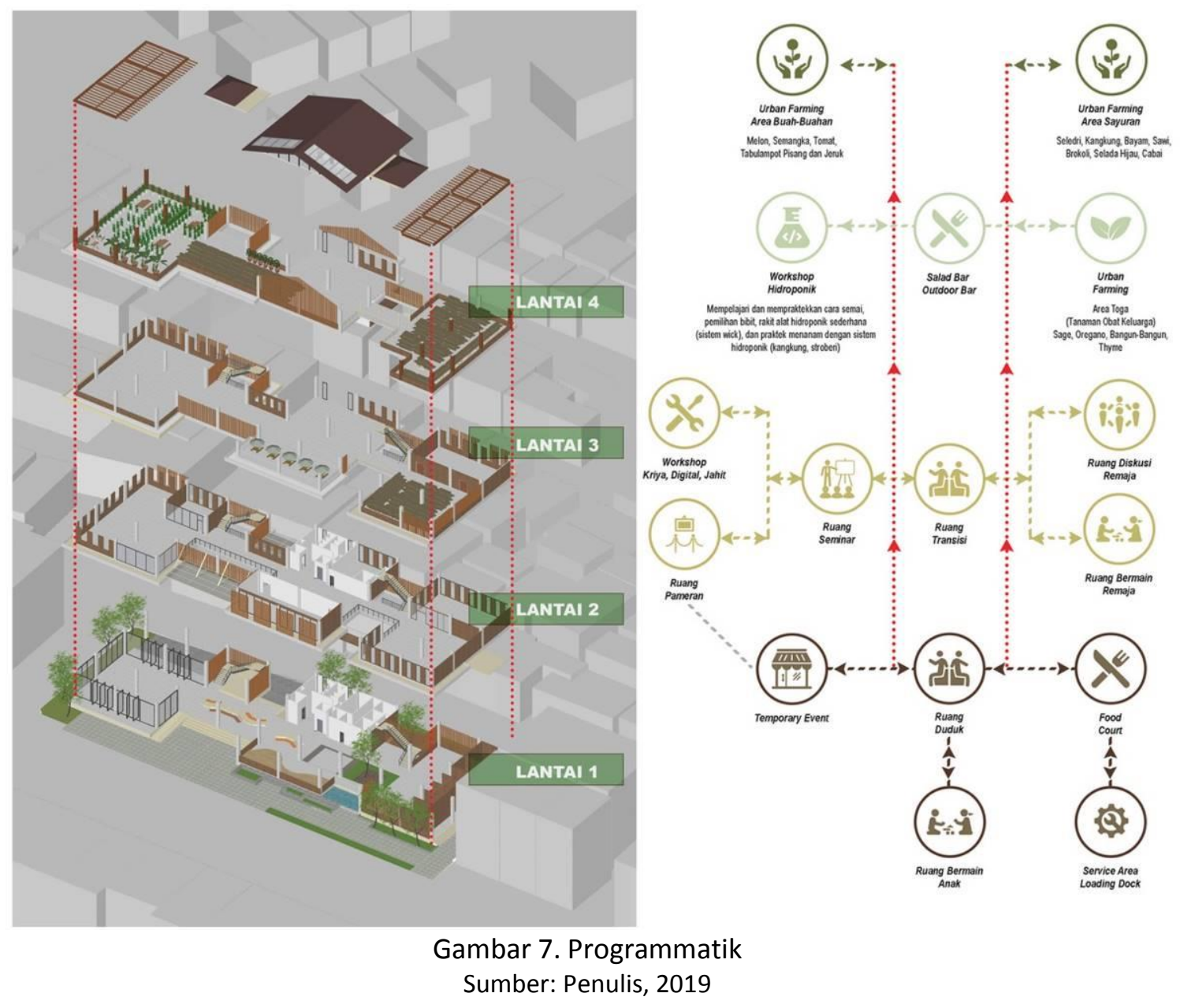

Lantai 2 terdiri dari zona garmen yang berupa workshop terbuka dengan meja-meja besar dan panjang dan ruang pajang hasil karya masyarakat. Workshop yang ada pada zona garmen lebih mengarah pada kegiatan jahit-menjahit untuk pengembangan masyarakat dan komunitas. Terdapat pula workshop digital design menggunakan photoshop yang berupa ruang kelas untuk menaikkan produktivitas dan kreativitas warga.

Sebagai pendukung workshop terdapat ruang seminar yang dapat digunakan ketika sewaktu-waktu terdapat narasumber atau sesama komunitas yang diundang untuk memberi pembelajaran mengenai hidroponik dan garmen. Ruang seminar ini juga dapat digunakan sebagai ruang rapat Rukun Warga atau kegiatan-kegiatan yang lebih formal. Terdapat juga kegiatan informal berupa ruang diskusi remaja dan tempat bermain indoor yang terbuka.

Area tanam hidroponik berada di lantai 3 dan 4 (rooftop) dan dibagi berdasarkan jenis kelompoknya. Pertama adalah zona TOGA atau Tanaman Obat keluarGA yang terdiri dari tanaman sage, oregano, bangun-bangun, dan thyme yang ditanam dengan sistem NFT. Kedua adalah zona buah yang terdiri dari melon, semangka, dan tomat yang ditanam dengan sistem drip, serta pisang dan jeruk yang ditanam dalam pot. Ketiga adalah zona sayur yang terdiri dari seledri, kangkung, bayam, sawi, brokoli, selada hijau, dan cabai yang ditanam dengan sistem NFT. Pengunjung pada area hidroponik dapat melihat-lihat sambil belajar mengenai berbagai tanaman yang ada secara gratis. Terdapat beberapa tempat duduk panjang yang dapat dijadikan tempat untuk bersantai dan piknik sambil dikelilingi penghijauan. Ketika masa panen, pengunjung diperbolehkan untuk memetik buah dan sayur dengan biaya tertentu. 


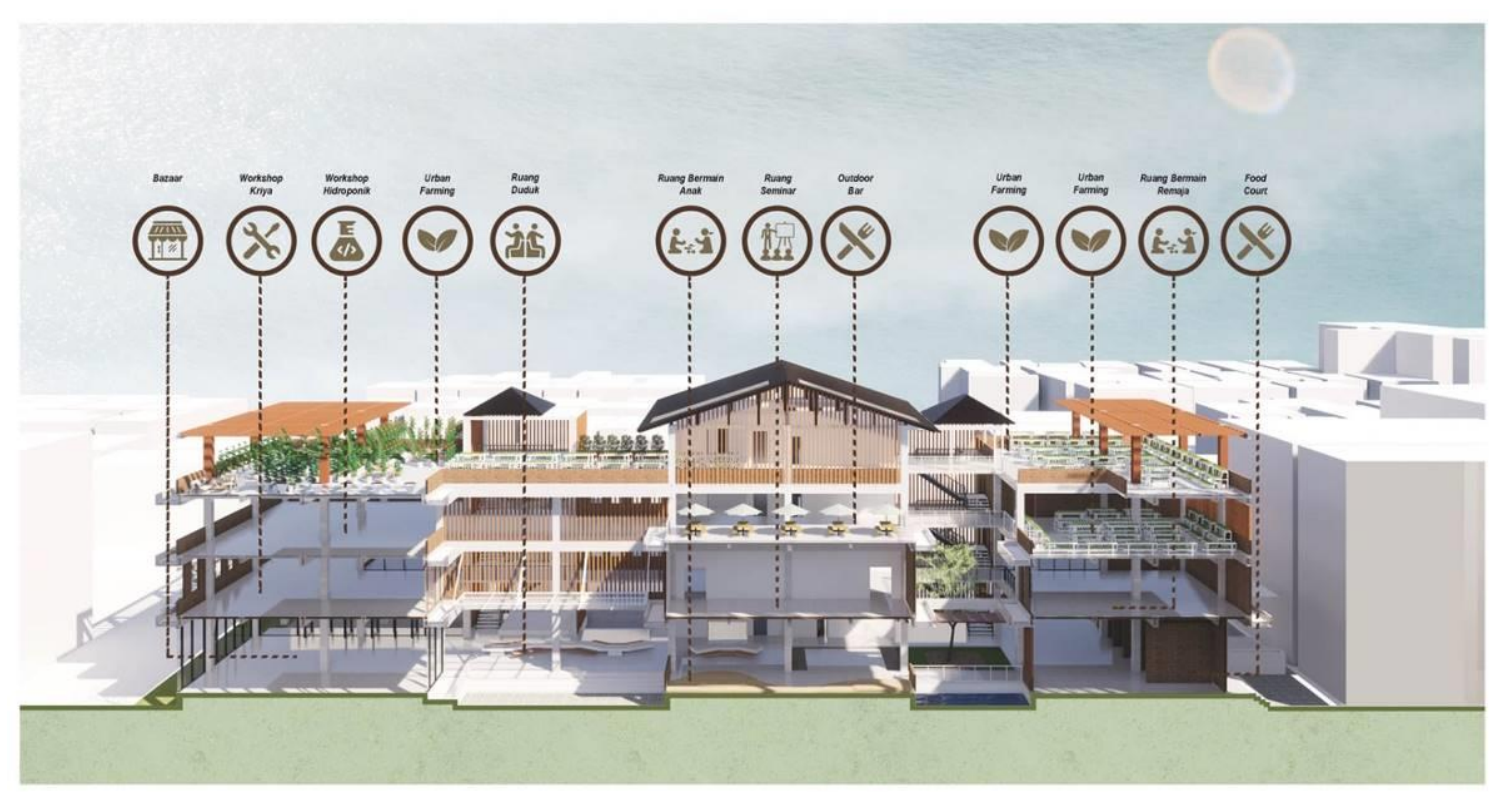

Gambar 8. Potongan Prespektif

Sumber: Penulis, 2019

Proyek lebih mengutamakan pencahayaan dan pengudaraan secara alami. Oleh karena itu, penampilan bangunan dibuat lebih sederhana dan terbuka dengan menggunakan perpaduan dinding parapet dan railing kaca. Atap bangunan berbentuk pelana dan perisai sebagai ciri bangunan tropis.
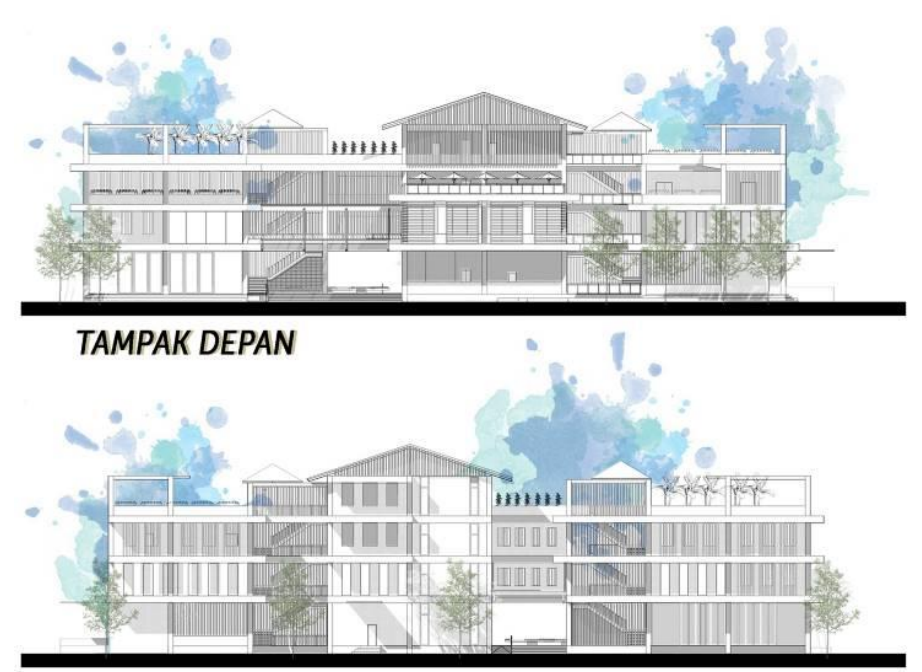

TAMPAK BELAKANG

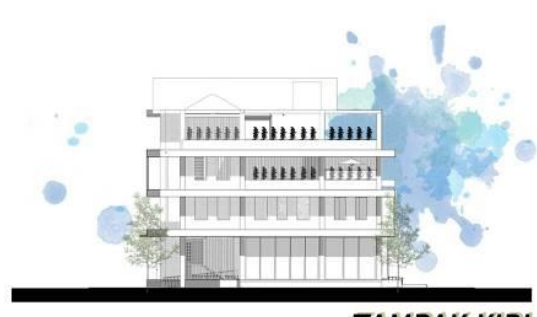

TAMPAK KIRI

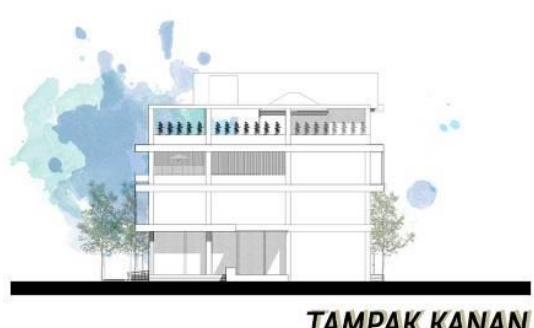

Gambar 9. Tampak Bangunan

Sumber: Penulis, 2019

Material bangunan menggunakan bata dan beton ekspos untuk memberikan kesan yang alami dan natural, dilengkapi kaca tempered dan dengan kisi-kisi kayu accoya sebagai aksen vertikal pada bangunan. Material utama adalah material yang tahan api sebagai respon bangunan terhadap lingkungan sekitar yang rentan kebakaran. 


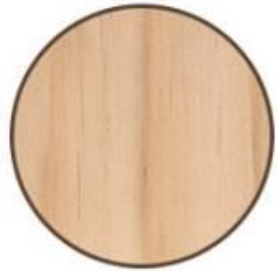

KAYU ACCOYA

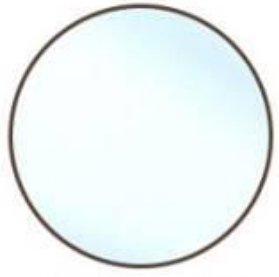

KACA TEMPERED

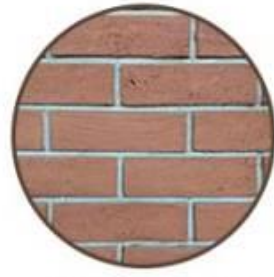

BATA EXPOSE

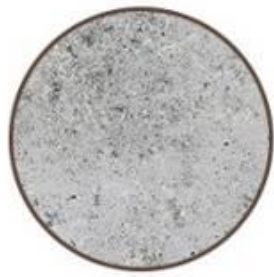

BETON EXPOSE

Gambar 10. Skematik Material Sumber: Penulis, 2019
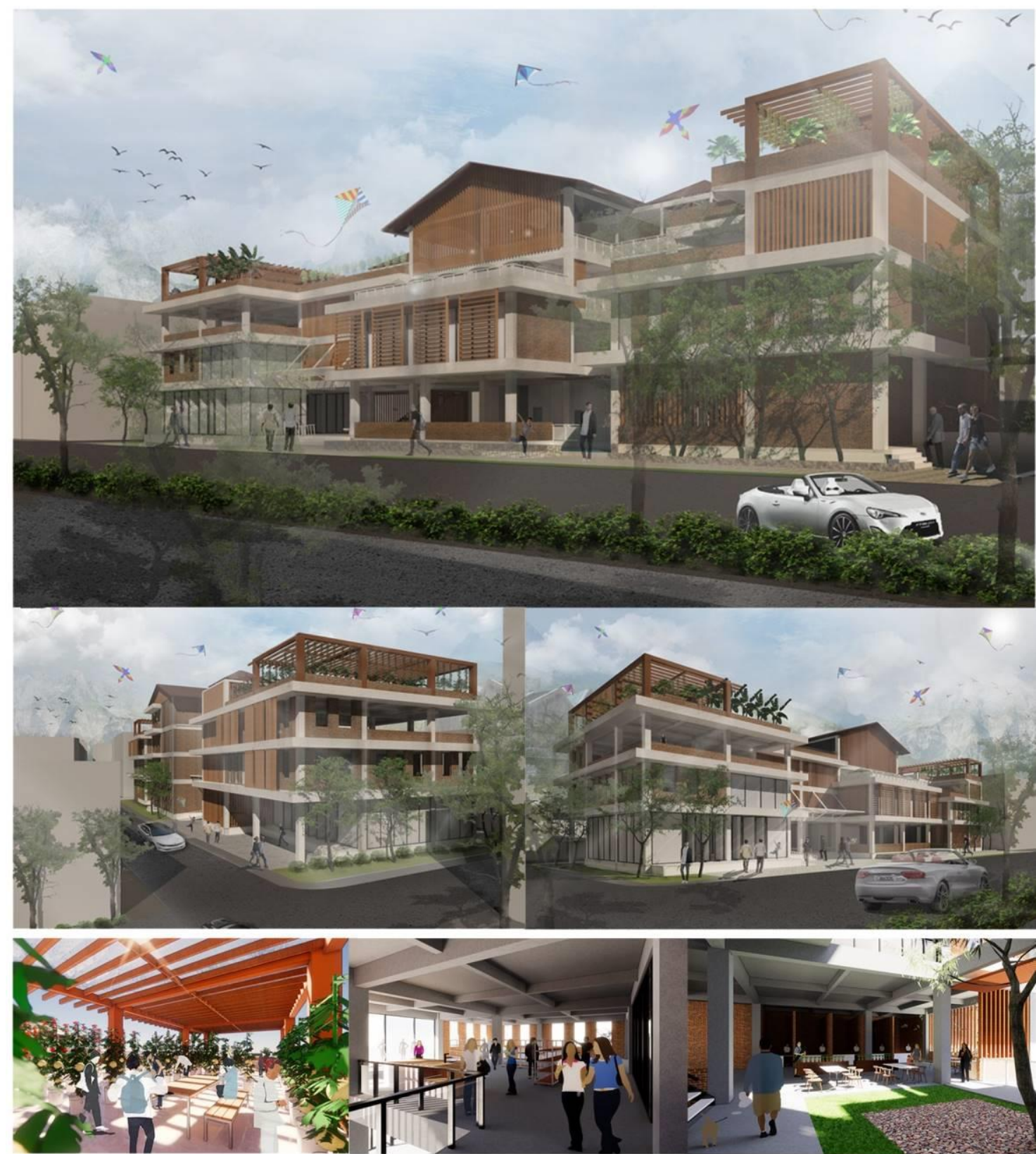

Gambar 11. Prespektif Eksterior dan Interior

Sumber: Penulis, 2019 


\section{KESIMPULAN DAN SARAN \\ Kesimpulan}

Third place adalah tempat di mana manusia dapat beraktivitas meluangkan waktu dengan sesamanya selain di rumah tinggal (first place) dan tempat kerja (second place). Third place dibutuhkan dalam lingkungan kota untuk menciptakan masyarakat yang lebih terbuka, dinamis, dan produktif.

Wadah Aktivitas Masyarakat di Tanah Sereal adalah third place yang bertujuan untuk menyediakan wadah aktivitas bersama yang layak bagi masyarakat padat penduduk di Tanah Sereal. Desainnya berfokus pada interaksi antar manusia dan manusia dengan alam, diterjemahkan dalam arsitektur mulai dari pembentukan massa bangunan yang memiliki solidvoid untuk membuka peluang adanya interaksi manusia secara visual dan penambahan unsur alam dalam bangunan seperti dengan adanya inner courtyard.

Program yang ada dalam bangunan didapat dari metode analisis-sintesis dari kebutuhan masyarakat dan kawasan. Program utama bangunan yaitu area tanam hidroponik (urban farming), dilengkapi dengan foodcourt, area bermain anak dan remaja, area diskusi remaja, area komunal, salad bar, serta ruang seminar dan balai serbaguna. Selain itu, terdapat pula program pengembangan masyarakat seperti workshop garmen dan workshop hidroponik yang bertujuan untuk meningkatkan skill, produktivitas, dan taraf hidup masyarakat sekitar. Proyek juga berfokus pada pengembalian ruang terbuka hijau untuk mengatasi masalah sosial dan lingkungan, sehingga menciptakan citra yang hijau dan harmonis di kawasan tersebut.

\section{Saran}

Desain third place yang baik haruslah disesuaikan dengan kebutuhan masyarakat setempat. Program-program yang ada juga sebaiknya dapat menunjang kehidupan sehari-hari masyarakat dan menciptakan masyarakat yang lebih terbuka, dinamis, dan produktif.

Pada kawasan padat seperti di Tanah Sereal dibutuhkan strategi arsitektur yang tidak menambah citra padat pada kawasan, salah satunya adalah mendesain ruang-ruang yang luas sehingga tidak mengingatkan masyarakat akan kesesakkan lingkungan sekitar. Pembangunan kedepan sebaiknya juga memperhatikan peraturan bangunan dan lebih berfokus pada pengembalian ruang terbuka hijau untuk mengatasi masalah sosial dan lingkungan, sehingga dapat menciptakan citra yang hijau dan harmonis bagi kota.

\section{REFERENSI}

Badan Pusat Statistik. (2018). Provinsi DKI Jakarta Dalam Angka 2018. Diunduh 26 Agustus 2019, dari https://jakarta.bps.go.id/publication/2018/08/16/67d90391b7996f51d1c625c4/provinsidki-jakarta-dalam-angka-2018.html

Budiharjo, E. dan D. Sujarto. (1999). Kota Berkelanjutan. Bandung: PT Alumni.

Central Intelligence Agency. (2018). The World Factbook 2018. Dipetik 27 Agustus 2019, dari https://www.cia.gov/library/publications/the-world-factbook/

Djaharuddin. (2018). Lokasi Terpadat di Asia Tenggara Ternyata Ada di Wilayah Tambora. Dipetik 27 Agustus 2019, dari https://jakarta.tribunnews.com/2018/03/05/lokasi-terpadatdi-asia-tenggara-ternyata-ada-di-wilayah-tambora

Indonesia Berkebun. (2015). Urban Farming Ala Indonesia Berkebun. Jakarta: Agro Media Pustaka.

Kristi, A.A. (2018). Hidroponik Rumahan - Modal di Bawah 600 Ribu. Yogyakarta: ANDI.

Lingga, P. (1986). Petunjuk Penggunaan Pupuk. Penebar Swadaya: Jakarta.

Lingga, P. (1999). Hidroponik Bercocok Tanam Tanpa Tanah. Penebar Swadaya: Jakarta.

Mantra, I.B. (2007). Demografi Umum. Yogyakarta: BPFE.

Widyawati, N. (2013). Urban Farming Gaya Bertani Spesifik Kota. Yogyakarta: ANDI. 
Oldenburg, R. (1999). The Great Good Place: Cafes, Coffee Shops, Bookstores, Bars, Hair Salons, and Other Hangout at the Heart of a Community. New York: Marlowe and Company.

Pemerintah Indonesia. (2007). Undang-Undang No. 26 Tahun 2007 tentang Penataan Ruang. Lembaran RI Tahun 2007 No. 26. Jakarta: Sekretariat Negara.

UN Habitat. (2016). UN report: By 2030 two-thirds of world will live in cities. Dipetik 26 Agustus 2019, dari https://apnews.com/40b530ac84ab4931874e1f7efb4f1a22/un-report2030-two-thirds-world-will-live-cities

https://jakartasatu.jakarta.go.id/

https://www.google.com/intl/id/earth/ 
